\title{
Magdalena BoczKowsKa
}

Uniwersytet Marii Curie-Skłodowskiej w Lublinie

\section{WARTOŚCI OSOBISTE PREFEROWANE PRZEZ MŁODZIEŻ GIMNAZJALNĄ A WYBRANE WSKAŹNIKI SOCJODEMOGRAFICZNE}

\begin{abstract}
Abstrakt: Jednym z podstawowych zadań rozwojowych na etapie adolescencji jest formowanie indywidualnej hierarchii wartości, która pełni na dalszych etapach życia funkcję regulacyjną w codziennej życiowej aktywności i dokonywaniu wyborów. Liczne badania wykazują, że młodzież preferuje wartości uniwersalne, a w małym stopniu uznaje wartości typowo hedonistyczne. W celu zdiagnozowania, z jakimi symbolami młodzież utożsamia szczęście i jakie wartości w jej życiu są nadrzędne, a także czy i w jakim stopniu wybrane czynniki socjodemograficzne różnicują w omawianym zakresie uczniów, przeprowadzono badanie z wykorzystaniem metody sondażu diagnostycznego. Jako narzędzie posłużyła Lista Wartości Osobistych autorstwa Zygfryda Juczyńskiego. Łącznie przebadano 375 uczniów szkół gimnazjalnych z terenu województwa lubelskiego. Deklarowane przez młodzież wartości osobiste najczęściej odnosiły się do rodziny, przyjaciól, dobrego zdrowia. Wartości hedonistyczne były przez badanych wybierane rzadko, przypisywano im także niskie rangi. Czynniki socjodemograficzne, jak miejsce zamieszkania, wykształcenie rodziców oraz subiektywna ocena sytuacji materialnej rodziny, różnicowały uczniów jedynie w wyborach pojedynczych symboli szczęścia i wartości osobistych. Płeć nie stanowiła czynnika różnicującego badanych w omawianym zakresie. Sfera aksjologiczna podlega stałym przemianom społecznym, kulturowym, edukacyjnym. Ważne wydają się więc działania dążące do wychowania w zgodzie z wartościami uniwersalnymi.
\end{abstract}

Słowa kluczowe: uczniowie gimnazjum, hierarchia wartości, symbole szczęścia osobistego. 


\section{WPROWADZENIE}

Tożsamość człowieka, jego indywidualna hierarchia wartości, symbole, z jakimi łączy poczucie szczęścia, rozwijają się w ciągu całego życia, kluczowy jest jednak etap adolescencji. Na przestrzeni kilku lat, które obejmują proces dorastania, dokonują się przemiany w wymiarach fizycznym, psychicznym i społecznym mające umożliwić jednostce podjęcie nowych ról społecznych i kolejnych zadań rozwojowych: „Osiągnięcie poczucia tożsamości będzie polegało na ukształtowaniu [...] silnego, spójnego systemu wartości oraz na «zdrowym» przystosowaniu do świata wypełnionego przez znaczące związki z ludźmi, pracą oraz zajęcia w czasie wolnym" (Ponczek, Olszowy 2012, s. 262). Jednym z najważniejszych zadań rozwojowych w tym okresie jest tworzenie indywidualnej hierarchii wartości, a co się z tym wiąże - formowanie własnej tożsamości.

Samo pojęcie „wartości” jest mało precyzyjne, dlatego też należy je odnieść do konkretnej subdyscypliny, w której będzie analizowane. W pedagogicznej koncepcji wychowania do wartości termin ten można definiować jako normy i zasady postępowania, które zostają potwierdzone w codziennych doświadczeniach i które umożliwiają optymalny rozwój wychowanka oraz osiągnięcie przez niego trwałej satysfakcji życiowej (Dziewiecki 2003, s. 154-155).

System wartości człowieka reguluje jego wybory i zachowania oraz służy wyrażaniu tego, co jest mu szczególnie bliskie. Wartości zatem stanowią regulator świadomego i celowego działania w różnych sytuacjach życiowych, jednak dopiero wówczas, gdy uzyskają wysoką pozycję w osobistej hierarchii, nie tylko w sferze deklaracji (Reykowski 1977). Struktura wartości osobistych jest kształtowana od dzieciństwa w procesie wychowawczym, a także przez doświadczanie zdarzeń życiowych. Istotną rolę, szczególnie w dzieciństwie, odgrywa system wartości rodziców, gdyż ma on związek $\mathrm{z}$ atmosferą panującą $\mathrm{w}$ domu rodzinnym i stosowanymi metodami wychowawczymi. Wartości przyjęte przez adolescentów muszą ulec zinternalizowaniu, aby odzwierciedlały się w ich zachowaniach. Internalizacja ma na celu przyjęcie i zaakceptowanie wartości, a do tego niezbędna jest zdolność do autorefleksji. Waldemar Furmanek (2011, s. 77-78) twierdzi, że internalizacja następuje „dzięki ich [wartości - uzup. M.B.] intelektualnemu zrozumieniu i akceptacji, wytworzeniu się pozytywnego stosunku emocjonalnego i podejmowaniu samodzielnych wyborów i idących za nimi działań na rzecz realizacji tych wartości”. W życiu młodzieży sfera wartości zajmuje szczególnie ważne miejsce, gdyż decyduje o sensie i jakości życia, reguluje stosunek do siebie i otaczającego środowiska (Marzec-Tarasińska 2014, s. 148). Ponadto hierarchia wartości nie jest konstruktem stałym, a ulega zmianom wraz z upływem czasu, nabytymi doświadczeniami oraz pod wpływem otoczenia i rzeczywistości społeczno-politycznej. 
Janusz Mariański (2009, s. 11) podkreśla, że współczesna młodzież kształtuje swoje hierarchie przez wybór z „katalogu wartości” tych, które wydają się najkorzystniejsze, mają za zadanie przynosić przyjemności i zaspokojenie różnorodnych potrzeb. Taki stan rzeczy prowadzić może do zachwiania sfery aksjologicznej i dokonywania wyborów typowo hedonistycznych. W sytuacji kryzysu wartości szczególnego znaczenia nabiera proces wychowania do wartości rozumiany nie tylko jako przekazywanie wiedzy na temat ich roli i znaczenia w życiu człowieka, ale również jako wsparcie w procesie ich internalizacji. Dogłębne zrozumienie i akceptacja poszczególnych wartości oraz tworzenie na ich podstawie własnej hierarchii jest jedyną drogą do kierowania się nimi w codziennym życiu.

Anna Zawada (2013, s. 14) zauważa, że system wartości nastolatków różni się ze względu na typ szkoły, do której uczęszczają, miejsce zamieszkania (duża aglomeracja, małe miasto, wieś), warunki ekonomiczne rodziny i jej kapitał kulturowy. Badania przeprowadzone przez autorkę wśród śląskiej młodzieży wykazały, że w osobistej hierarchii wartości młodzież najwyżej ceni rodzinę, troskę o zdrowie swoje i rodziny, posiadanie przyjaciół oraz dobrobyt. Niskie oceny uzyskały takie wartości, jak: sukces i sława, religia i rozwój duchowy, bezpieczeństwo narodowe, pomyślność ojczyzny, życie pełne przygód i wrażeń (tamże, s. 357).

Badania przeprowadzone przez Małgorzatę Dubis (2014) wśród 280 licealistów klas maturalnych szkół publicznych i niepublicznych dowiodły, że największym uznaniem wśród uczniów szkół publicznych cieszą się takie wartości, jak: rodzina (98,5\%), miłość $(92,2 \%)$, szczęście (81,4\%), wykształcenie (76,4\%). Najmniej ważne są zaś w tej grupie: sztuka, rozrywka, przyjemność oraz sława. Autorka przeanalizowała też dane z uwzględnieniem miejsca zamieszkania. Uzyskane wyniki pokazały, że bez względu na miejsce zamieszkania najwyżej cenioną wartością jest rodzina.

Jarosław Domalewski (2013) przeprowadził badania wśród młodzieży gimnazjalnej, które wykazały, że najwyżej ceni ona udane życie rodzinne, posiadanie przyjaciół, dobre wykształcenie i interesującą pracę. Wartości, które były najrzadziej wybierane przez badanych to rozrywka i majątek.

Badania przeprowadzone przez Zdzisławę Chmiel-Połeć, Lucynę Boratyn-Dubiel i Monikę Binkowską-Bury (2007) wśród 193 uczniów gimnazjum z powiatu rzeszowskiego dowiodły, że chłopcy i dziewczęta różnią się w preferowaniu pewnych wartości osobistych. Zaobserwowane różnice dotyczyły takich wartości, jak: zdobycie sławy $(\mathrm{p}<0,001)$, posiadanie pieniędzy i dobrego zdrowia $(\mathrm{p}<0,01)$, szczęście rodzinne $(\mathrm{p}<0,05)$. Dziewczęta wyżej cenią zdrowie i szczęście rodzinne, natomiast niższe pozycje w porównaniu do chłopców przypisują sławie i posiadaniu pieniędzy. W badaniach stwierdzono także, że miejsce zamieszkania jest czynnikiem różnicującym w zakresie takich wartości, jak zdobycie sławy i zdrowia $(\mathrm{p}<0,01)$ oraz 
posiadanie pieniędzy $(\mathrm{p}<0,05)$. Uczniowie zamieszkujący wieś cenią zdrowie wyżej niż zamieszkający miasto.

Powyższe ustalenia skłaniają do głębszych refleksji dotyczących hierarchii wartości i symboli, z którymi młodzież gimnazjalna wiąże poczucie szczęścia.

\section{BADANIA WŁASNE}

Przeprowadzone badania miały na celu poznanie hierarchii wartości uczniów szkół gimnazjalnych oraz socjodemograficznych korelatów tych wartości. Sformułowano następujące problemy badawcze:

1) Jakie wartości i symbole szczęścia preferują uczniowie szkół gimnazjalnych?

2) Czy (a jeśli tak, to w jakim zakresie) wybrane czynniki socjodemograficzne (płeć badanych, miejsce zamieszkania, wykształcenie rodziców, subiektywna ocena sytuacji materialnej rodziny) różnicują wyznawane przez młodzież gimnazjalną wartości i preferowane symbole szczęścia osobistego?

W badaniach posłużono się metodą sondażu diagnostycznego. Jako narzędzie wykorzystano Listę Wartości Osobistych opracowaną przez Zygfryda Juczyńskiego. Analiza składa się z dwóch części. Pierwsza $\mathrm{z}$ nich zawiera opis dziewięciu symboli szczęścia, które wyrażają różne formy aktualizacji wartości. Druga część przedstawia dziesięć kategorii wartości osobistych. Celem badania jest ocena znaczenia przypisywanego różnym wartościom. Metoda służy do badania dzieci i młodzieży, może być jednak używana również do badania osób dorosłych: zdrowych i chorych. Rzetelność LWO dla obydwu jej części wynosi 0,78 i 0,76 (test-retest), a trafność teoretyczna - 0,74 (Juczyński 2009). Przeciętny czas badania nie przekracza dziesięciu minut. Aby uzyskać odpowiedź na drugie pytanie badawcze zastosowano jednoczynnikową wariancję ANOVA przy użyciu pakietu statystycznego PS IMAGO (SPSS Statistics 22).

Łącznie przebadano 375 uczniów szkół gimnazjalnych znajdujących się na terenie województwa lubelskiego. Badania odbywały się w trakcie zajęć lekcyjnych, po uzyskaniu zgody dyrekcji szkoły, rodziców i samych uczniów. Dziewczęta stanowiły 58\% badanych (217 osób), a chłopcy - 42\% (158 osób); 50,4\% uczniów pochodziło $\mathrm{z}$ dużego miasta (189 osób), 28\% z małego miasta (105 osób), a 21,6\% badanych ze wsi (81 osób). Uczniowie deklarowali najczęściej, iż ich ojcowie mają wykształcenie średnie (33,9\% badanych), rzadziej - zawodowe (29,6\%), a 23,7\% badanych odpowiedziało, iż ich ojcowie mają wykształcenie wyższe. Odpowiedzi na to pytanie nie udzieliło 8\% uczniów (30 osób). Młodzież, określając poziom wykształcenia 
swoich matek, najczęściej wskazywała na wykształcenie wyższe (34,4\% badanych), w następnej kolejności - wykształcenie średnie $(33,1 \%)$, a na końcu - zawodowe $(18,9 \%)$ i podstawowe (6\%). Żadnej odpowiedzi nie zaznaczyło 7,7\% badanych. Najczęściej młodzież określała sytuację materialną swojej rodziny jako raczej dobrą (46,9\% badanych), rzadziej jako przeciętną $(25,9 \%)$, bardzo dobrą $(23,5 \%)$ oraz raczej złą (3,5\%). Nikt spośród respondentów nie ocenił sytuacji materialnej rodziny jako bardzo złej.

\section{WYNIKI BADAŃ}

Uczniowie za najważniejszy symbol szczęścia (posiadający najwyższą średnią wagę) uznali udane życie rodzinne $(2,9)$. Połowa badanych przypisała temu symbolowi czwartą (21\%) lub piątą $(28,8 \%)$ rangę. Kolejnym ważnym symbolem szczęścia okazał się dla gimnazjalistów duży krąg przyjaciół $(2,53)$, jednak co piąty uczeń w ogóle nie wybrał tego symbolu. Uczniowie, którzy utożsamiają szczęście z posiadaniem dużej liczby przyjaciół, najczęściej przypisywali temu symbolowi wysoką, czwartą rangę (19,5\%). Następnym w kolejności symbolem szczęścia jest dobre zdrowie $(2,46)$. Jednak 20,3\% uczniów nie dokonało wyboru tego symbolu. Badani, dla których dobre zdrowie jest wyznacznikiem szczęścia, najczęściej przypisywali mu trzecią $(19,7 \%)$ lub drugą $(18,1 \%)$ rangę. Zaledwie 15,7\% uczniów wskazało na sławę i popularność jako symbole szczęścia, były one zatem najmniej popularne wśród młodzieży, podobnie jak życie pełne przygód i podróży (średnia waga wyniosła 1,16). Symbol ten zaznaczył co drugi uczeń, najczęściej jednak przypisywano mu najniższą, pierwszą rangę (17,3\%).

Tabela 1. Symbole szczęścia preferowane przez młodzież gimnazjalną $(\mathrm{N}=375)$

\begin{tabular}{|c|c|c|c|c|c|c|c|c|}
\hline \multirow{2}{*}{ Lp. } & \multirow{2}{*}{ Symbole szczęścia } & \multirow{2}{*}{$\begin{array}{c}\text { Średnia } \\
\text { waga }\end{array}$} & \multicolumn{6}{|c|}{ Rangi (wybory w \%) } \\
\hline & & & 1 & 2 & 3 & 4 & 5 & 0 \\
\hline 1. & udane życie rodzinne & 2,9 & 12,3 & 8,8 & 10,4 & 21,0 & 28,8 & 18,7 \\
\hline 2. & duży krąg przyjaciół & 2,53 & 10,4 & 15,2 & 16,3 & 19,5 & 17,0 & 21,6 \\
\hline 3. & dobre zdrowie & 2,46 & 10,4 & 18,1 & 19,7 & 17,1 & 14,4 & 20,3 \\
\hline 4. & bycie potrzebnym dla innych ludzi & 1,59 & 8,3 & 9,1 & 12,0 & 11,2 & 10,4 & 49,0 \\
\hline 5. & wykonywanie ulubionej pracy, zawodu & 1,36 & 9,1 & 10,6 & 11,2 & 9,1 & 7,2 & 52,8 \\
\hline 6. & sukcesy w nauce, pracy & 1,36 & 14,4 & 12,0 & 11,5 & 10,7 & 4,8 & 46,6 \\
\hline 7. & dobre warunki materialne & 1,22 & 10,9 & 11,5 & 9,1 & 5,6 & 7,7 & 55,2 \\
\hline 8. & życie pełne przygód, podróży & 1,16 & 17,3 & 11,7 & 7,5 & 4,8 & 6,7 & 52,0 \\
\hline 9. & sława, popularność & 0,38 & 6,7 & 2,4 & 2,9 & 1,0 & 2,7 & 84,3 \\
\hline
\end{tabular}

Źródło: opracowanie własne. 
Wartościami, które wśród badanych uzyskały największą średnia wagę $(3,4)$ są miłość i przyjaźń - co drugi uczeń przyznał im najwyższą, piątą rangę (51,7\%). Na drugim miejscu znalazło się dobre zdrowie utożsamiane ze sprawnością fizyczną i psychiczną - niemalże co piąty uczeń przypisał mu wysoką, czwartą rangę. Należy jednak zaznaczyć, że 35\% badanych w ogóle nie dokonała wyboru tej wartości. Dla młodzieży wydają się istotne również poczucie humoru, dowcip (średnia waga -1,51), chociaż te wartości wybrała jedynie nieco ponad połowa uczniów, przypisując im różne rangi. Najmniej popularnymi wartościami wśród badanych były bogactwo i majątek - wybrał je zaledwie co piąty uczeń (średnia waga - 0,57). Takie wartości jak ładny wygląd zewnętrzny, prezencja również zdają się nie mieć większego znaczenia dla uczniów, gdyż tylko 29,1\% badanych na nie wskazało, najczęściej przypisując im najniższą, pierwszą rangę (10,1\%).

Tabela 2. Wartości osobiste preferowane przez młodzież gimnazjalną $(\mathrm{N}=375)$

\begin{tabular}{|c|l|r|r|r|r|r|r|c|}
\hline \multirow{2}{*}{ Lp. Wartości osobiste } & Średnia & \multicolumn{5}{|c|}{ Rangi (wybory w \%) } \\
\cline { 5 - 8 } & & waga & 1 & 2 & 3 & 4 & 5 & 0 \\
\hline 1. & miłość, przyjaźń & 3,40 & 18,4 & 7,2 & 4,3 & 9,1 & 51,7 & 9,3 \\
\hline 2. & dobre zdrowie, sprawność fizyczna i psychiczna & 2,12 & 8,5 & 12,0 & 12,5 & 19,5 & 12,8 & 35,0 \\
\hline 3. & poczucie humoru, dowcip & 1,51 & 11,7 & 13,1 & 12,0 & 13,6 & 4,5 & 45,1 \\
\hline 4. & inteligencja, bystrość umysłu & 1,72 & 7,7 & 12,0 & 17,1 & 16,0 & 5,1 & 42,1 \\
\hline 5. & wiedza, mądrość & 1,34 & 7,5 & 10,9 & 14,4 & 10,4 & 4,0 & 52,8 \\
\hline 6. & odwaga, stanowczośćn & 1,68 & 10,9 & 17,3 & 16,3 & 12,8 & 4,5 & 38,1 \\
\hline 7. & radość, zadowolenie & 1,06 & 14,1 & 11,7 & 8,3 & 58,7 & 4,0 & 56,0 \\
\hline 8. & dobroć. Delikatność & 0,85 & 3,7 & 7,2 & 6,1 & 6,1 & 4,8 & 72,0 \\
\hline 9. & ladny wygląd zewnętrzny, prezencja & 0,73 & 10,1 & 5,6 & 4,8 & 5,3 & 3,2 & 70,9 \\
\hline 10. & bogactwo, majątek & 0,57 & 6,9 & 2,7 & 4,3 & 1,3 & 5,3 & 79,5 \\
\hline
\end{tabular}

Źródło: opracowanie własne.

Powyższe analizy pozwalają na wysnucie wniosku, że młodzież preferuje tradycyjne wartości - rodzinę, miłość, przyjaźń.

PŁEĆ

W celu zweryfikowania, czy istnieją różnice w preferowanych symbolach szczęścia i wartościach osobistych wśród dziewcząt i chłopców, dokonano jednoczynnikowej analizy wariancji ANOVA. Pozwala ona na wysnucie wniosku, że płeć nie jest istotnym czynnikiem determinującym deklarowaną hierarchię wartości wśród młodzieży uczęszczającej do gimnazjum. Zaobserwowane różnice między dziewczętami a chłopcami dotyczą przede wszystkim takich symboli, jak: udane życie rodzinne (średnia waga dla dziewcząt - 3,46, a dla chłopców -3,70) oraz sława, popularność 
(średnia waga dla dziewcząt - 2,54, a dla chłopców - 2,21). Dziewczęta częściej niż chłopcy zdają się utożsamiać poczucie szczęścia ze sławą. Chłopcy natomiast bardziej niż dziewczęta doceniają życie rodzinne. Mimo zaobserwowanych różnic między średnimi, analizy statystycznie nie pozwalają na wysnucie wniosku, iż różnice te są istotne statystycznie.

Tabela 3. Symbole szczęścia preferowane przez dziewczęta i chłopców w wieku gimnazjalnym

\begin{tabular}{|c|l|c|c|c|c|}
\hline \multirow{2}{*}{ Lp. } & \multicolumn{1}{|c|}{ Symbol szczęścia } & Dziewczęta & Chłopcy & \multirow{2}{*}{ F } & \multirow{2}{*}{$\mathrm{p}$} \\
\cline { 3 - 4 } & & Średnia waga & Średnia waga & & \\
\hline 1. & duży krąg przyjaciół & 3,24 & 3,21 & 0,03 & 0,87 \\
\hline 2. & udane życie rodzinne & 3,46 & 3,70 & 2,16 & 0,14 \\
\hline 3. & wykonywanie ulubionej pracy, zawodu & 2,96 & 2,79 & 0,66 & 0,42 \\
\hline 4. & sukcesy w nauce, pracy & 2,64 & 2,57 & 0,14 & 0,71 \\
\hline 5. & dobre zdrowie & 2,43 & 2,50 & 0,14 & 0,71 \\
\hline 6. & bycie potrzebnym innym ludziom & 3,12 & 3,14 & 0,00 & 0,93 \\
\hline 7. & dobre warunki materialne & 2,79 & 2,66 & 0,33 & 0,56 \\
\hline 8. & życie pełne przygód & 1,12 & 1,20 & 0,23 & 0,63 \\
\hline 9. & sława, popularność & 2,54 & 2,21 & 0,69 & 0,41 \\
\hline
\end{tabular}

Źródło: opracowanie własne.

Również w przypadku preferowanych przez młodzież wartości różnice między średnimi okazały się nieistotne statystycznie. Jedynie wartości wiedza, mądrość wydają się bardziej docenianie wśród dziewcząt niż wśród chłopców (średnia dla dziewcząt - 2,97, dla chłopców - 2,67).

Tabela 4. Wartości osobiste preferowane przez dziewczęta i chłopców w wieku gimnazjalnym

\begin{tabular}{|c|l|c|c|c|c|}
\hline \multirow{2}{*}{ Lp. } & \multicolumn{1}{|c|}{ Wartości osobiste } & Dziewczęta & Chłopcy & \multirow{2}{*}{ F } & \multirow{2}{*}{$\mathrm{p}$} \\
\cline { 3 - 5 } & & Średnia waga & Średnia waga & & \\
\hline 1. & miłość, przyjaźń & 3,69 & 3,85 & 0,75 & 0,39 \\
\hline 2. & dobre zdrowie, sprawność fizyczna i psychiczna & 3,17 & 3,35 & 1,18 & 0,28 \\
\hline 3. & poczucie humoru, dowcip & 2,68 & 2,82 & 0,60 & 0,44 \\
\hline 4. & inteligencja, bystrość umysłu & 2,89 & 3,10 & 1,69 & 0,19 \\
\hline 5. & wiedza, mądrość & 2,97 & 2,67 & 2,79 & 0,09 \\
\hline 6. & radość, zadowolenie & 2,81 & 2,59 & 1,94 & 0,16 \\
\hline 7. & odwaga, stanowczośćn & 2,48 & 2,30 & 0,80 & 0,37 \\
\hline 8. & dobroć, delikatność & 2,92 & 3,20 & 1,19 & 0,28 \\
\hline 9. & ladny wygląd zewnętrzny, prezencja & 2,58 & 2,41 & 0,40 & 0,53 \\
\hline 10. & bogactwo, majątek & 3,03 & 2,55 & 1,72 & 0,19 \\
\hline
\end{tabular}

Źródło: opracowanie własne. 
Przeprowadzone analizy nie pozwalają na wysnucie wniosku o istotnych różnicach między dziewczętami a chłopcami w wieku gimnazjalnym w zakresie preferowanych symboli szczęścia i wartości osobistych.

\section{MIEJSCE ZAMIESZKANIA}

W dalszej kolejności przeanalizowano, czy miejsce zamieszkania (duże miasto, małe miasto, wieś) różnicuje istotnie wyniki w zakresie symboli szczęścia i preferowanych wartości wśród badanej młodzieży gimnazjalnej. Udane życie rodzinne najwyższą średnią uzyskało wśród mieszkańców dużych miast $(3,76)$. Wykonywanie ulubionej pracy, zawodu wydaje się bardziej doceniane przez uczniów mieszkających w małych miastach $(3,06)$, natomiast sukcesy w nauce, pracy - ważniejsze dla badanych z dużych niż małych miast i wsi. Wśród mieszkańców wsi bycie potrzebnym dla innych ludzi jest symbolem, który uzyskał wyższą średnią niż w pozostałych analizowanych grupach. Pomimo zaobserwowanych różnic między średnimi, nieuprawnione wydaje się wysnucie wniosku, że są one istotne statystycznie. Jedynie w przypadku symbolu, jakim jest udane życie rodzinne, można uznać, że zaistniałe różnice są na granicy istotności statystycznej $(\mathrm{p}=0,06)$.

Tabela 5. Symbole szczęścia preferowane przez młodzież gimnazjalną z uwzględnieniem miejsca zamieszkania

\begin{tabular}{|c|l|c|c|c|c|c|}
\hline \multirow{2}{*}{ Lp. } & \multicolumn{1}{|c|}{ Symbol szczęścia } & Duże miasto & Małe miasto & Wieś & \multirow{2}{*}{ F } & p \\
\cline { 3 - 5 } & & $\begin{array}{c}\text { Średnia } \\
\text { waga }\end{array}$ & $\begin{array}{c}\text { Średnia } \\
\text { waga }\end{array}$ & $\begin{array}{c}\text { Średnia } \\
\text { waga }\end{array}$ & & \\
\hline 1. & duży krąg przyjaciół & 3,23 & 3,23 & 3,20 & 1,02 & 0,98 \\
\hline 2. & udane życie rodzinne & 3,76 & 3,28 & 3,48 & 2,90 & 0,06 \\
\hline 3. & wykonywanie ulubionej pracy, zawodu & 2,86 & 3,06 & 2,77 & 0,59 & 0,55 \\
\hline 4. & sukcesy w nauce, pracy & 2,80 & 2,67 & 2,18 & 3,77 & 0,25 \\
\hline 5. & dobre zdrowie & 2,38 & 2,25 & 2,81 & 3,05 & 0,49 \\
\hline 6. & bycie potrzebnym innym ludziom & 3,11 & 2,88 & 3,38 & 1,77 & 0,17 \\
\hline 7. & dobre warunki materialne & 2,53 & 2,91 & 2,87 & 1,35 & 0,26 \\
\hline 8. & życie pełne przygód & 1,17 & 1,34 & 0,96 & 1,50 & 0,22 \\
\hline 9. & sława, popularność & 2,22 & 2,71 & 2,54 & 0,58 & 0,56 \\
\hline
\end{tabular}

Źródło: opracowanie własne.

Analizując wartości osobiste preferowane przez młodzież, można uznać, że miłość i przyjaźń są wyżej cenione przez mieszkańców dużych miast i wsi niż przez uczniów pochodzących z małych miast. Różnice okazały się istotne statystycznie $(\mathrm{p}=0,05)$. W przypadku pozostałych symboli szczęścia, mimo braku różnic statystycznie istotnych, daje się zauważyć, że inteligencja i bystrość umysłu stanowią 
symbole częściej wybierane przez mieszkańców dużych miast w przeciwieństwie do odwagi, stanowczości, które większą średnia wagę uzyskały wśród mieszkańców małych miast i wsi. Również w przypadku wartości, jakimi są bogactwo i posiadanie majątku, wyższe średnie wagi niż mieszkańcy dużych miast uzyskiwali uczniowie mieszkający na wsi lub w małych miastach.

Tabela 6. Wartości osobiste preferowane przez młodzież gimnazjalną z uwzględnieniem miejsca zamieszkania

\begin{tabular}{|c|c|c|c|c|c|c|}
\hline \multirow[b]{2}{*}{ Lp. } & \multirow[b]{2}{*}{ Wartości osobiste } & Duże miasto & Małe miasto & Wieś & \multirow[b]{2}{*}{$\mathrm{F}$} & \multirow[b]{2}{*}{$\mathrm{p}$} \\
\hline & & $\begin{array}{c}\text { Średnia } \\
\text { waga }\end{array}$ & $\begin{array}{c}\text { Średnia } \\
\text { waga }\end{array}$ & $\begin{array}{c}\text { Średnia } \\
\text { waga }\end{array}$ & & \\
\hline 1. & miłość, przyjaźń & 3,89 & 3,41 & 3,88 & 2,88 & 0,05 \\
\hline 2. & dobre zdrowie, sprawność fizyczna i psychiczna & 3,29 & 3,28 & 3,11 & 0,40 & 0,67 \\
\hline 3. & poczucie humoru, dowcip & 2,75 & 2,83 & 2,67 & 0,22 & 0,79 \\
\hline 4. & inteligencja, bystrość umysłu & 3,13 & 2,84 & 2,85 & 1,59 & 0,21 \\
\hline 5. & wiedza, mądrość & 2,73 & 2,91 & 2,96 & 0,68 & 0,51 \\
\hline 6. & radość, zadowolenie & 2,78 & 2,79 & 2,51 & 1,13 & 0,32 \\
\hline 7. & odwaga, stanowczość & 2,20 & 2,55 & 2,56 & 1,58 & 0,21 \\
\hline 8. & dobroć, delikatność & 2,89 & 3,41 & 2,94 & 1,48 & 0,23 \\
\hline 9. & $\begin{array}{l}\text { ładny wygląd zewnętrzny, } \\
\text { prezencja }\end{array}$ & 2,52 & 2,41 & 2,64 & 0,19 & 0,83 \\
\hline 10. & bogactwo, majątek & 2,51 & 3,17 & 2,92 & 1,33 & 0,27 \\
\hline
\end{tabular}

Źródło: opracowanie własne.

Podsumowując, należy podkreślić, że w przypadku czynnika, jakim jest miejsce zamieszkania, istotne różnice zaobserwowano jedynie w wyborach symbolu szczęścia: udane życie rodzinne oraz wartości: miłość, przyjaźń.

\section{WYKSZTAŁCENIE RODZICÓW}

Proces budowania systemu wartości w okresie adolescencji jest uzależniony w dużej mierze od pierwotnego środowiska socjalizacyjnego - rodziny. Rodzice stanowiący dla nastolatka osoby znaczące, mimo jego chęci uniezależnienia się i potrzeby autonomii, nadal są ważnym punktem odniesienia. Prawidłowe relacje w rodzinie stanowią bufor chroniący młodego człowieka przed zagrożeniami, które płyną z otoczenia. Przeanalizowano, w jakim stopniu preferowane symbole szczęścia i wartości osobiste są zróżnicowane przez zmienną „wykształcenie rodziców”. 


\section{Wykształcenie ojca}

Pierwszym krokiem była próba uchwycenia różnic między średnimi wagami dla symboli szczęścia wybieranych przez młodzież, której ojcowie posiadali wykształcenie podstawowe, zawodowe, średnie i wyższe. Różnice na granicy istotności statystycznej $(p=0,07)$ zanotowano w przypadku symbolu, jakim jest bycie potrzebnym dla innych ludzi - najwyższą średnią wagę tego symbolu zaobserwowano wśród uczniów, których ojcowie posiadali wyższe wykształcenie. Dobre warunki materialne i sława, popularność stanowiły symbole wyżej oceniane przez uczniów, których ojcowie posiadali wykształcenie zawodowe, jednak różnice te okazały się nieistotne statystycznie. Mimo braku różnic istotnych statystycznie na podkreślenie zasługuje fakt, że uczniowie, których ojcowie posiadali wykształcenie podstawowe, wyżej niż pozostali cenili dobre zdrowie.

Tabela 7. Symbole szczęścia preferowane przez młodzież gimnazjalną z uwzględnieniem poziomu wykształcenia ojców

\begin{tabular}{|c|l|c|c|c|c|c|c|}
\hline \multirow{2}{*}{ Lp. } & \multicolumn{1}{|c|}{ Symbol szczęścia } & Podstawowe & Zawodowe & Średnie & Wyższe & \multirow{2}{*}{} & \\
\cline { 3 - 6 } & & $\begin{array}{c}\text { Średnia } \\
\text { waga }\end{array}$ & $\begin{array}{c}\text { Średnia } \\
\text { waga }\end{array}$ & $\begin{array}{c}\text { Średnia } \\
\text { waga }\end{array}$ & $\begin{array}{c}\text { Średnia } \\
\text { waga }\end{array}$ & & F \\
\hline 1. & duży krąg przyjaciół & 3,00 & 3,07 & 3,33 & 3,17 & 1,17 & 0,32 \\
\hline 2. & udane życie rodzinne & 4,25 & 3,56 & 3,54 & 3,35 & 1,46 & 0,21 \\
\hline 3. & wykonywanie ulubionej pracy, zawodu & 3,00 & 3,04 & 2,76 & 2,91 & 0,38 & 0,82 \\
\hline 4. & sukcesy w nauce, pracy & 2,50 & 2,47 & 2,88 & 2,53 & 1,08 & 0,37 \\
\hline 5. & dobre zdrowie & 3,17 & 2,23 & 2,56 & 2,57 & 1,77 & 0,13 \\
\hline 6. & bycie potrzebnym innym ludziom & 2,36 & 3,31 & 3,07 & 3,34 & 2,15 & 0,07 \\
\hline 7. & dobre warunki materialne & 2,43 & 3,11 & 2,52 & 2,62 & 1,38 & 0,24 \\
\hline 8. & życie pełne przygód & 0,83 & 1,29 & 1,06 & 1,17 & 0,56 & 0,69 \\
\hline 9. & sława, popularnośćn & 1,67 & 2,93 & 1,96 & 2,43 & 1,76 & 0,15 \\
\hline
\end{tabular}

Źródło: opracowanie własne.

Dalsze analizy pozwoliły uchwycić różnice między średnimi obliczonymi na podstawie częstotliwości wyborów wartości osobistych preferowanych przez uczniów, których ojcowie posiadali wykształcenie podstawowe, zawodowe, średnie i wyższe. Statystycznie istotne różnice zaobserwowano w przypadku wartości, jaką jest radość, zadowolenie $(\mathrm{p}=0,04)$ - uzyskała ona wyższą wagę wśród uczniów, których ojcowie posiadali wykształcenie wyższe i podstawowe niż zawodowe i średnie. W przypadku pozostałych wartości nie zanotowano różnic istotnych statystycznie, jednak na uwagę zasługuje fakt, że dobroć i delikatność wśród uczniów, których ojcowie posiadali wykształcenie zawodowe były mniej doceniane niż w pozostałych grupach, natomiast wyższą średnią wagę zaobserwowano w tej grupie w przypadku wartości bogactwo, majątek. 
Tabela 8. Wartości osobiste preferowane przez młodzież gimnazjalną $\mathrm{z}$ uwzględnieniem poziomu wykształcenia ojców

\begin{tabular}{|c|c|c|c|c|c|c|c|}
\hline \multirow[b]{2}{*}{ Lp. } & \multirow[b]{2}{*}{ Wartości osobiste } & Podstawowe & Zawodowe & Średnie & Wyższe & \multirow[b]{2}{*}{$\mathrm{F}$} & \multirow[b]{2}{*}{$\mathrm{P}$} \\
\hline & & $\begin{array}{c}\text { Średnia } \\
\text { waga }\end{array}$ & $\begin{array}{c}\text { Średnia } \\
\text { waga }\end{array}$ & $\begin{array}{c}\text { Średnia } \\
\text { waga }\end{array}$ & $\begin{array}{c}\text { Średnia } \\
\text { waga }\end{array}$ & & \\
\hline 1. & miłość, przyjaźń & 3,50 & 3,73 & 3,89 & 3,62 & 0,43 & 0,78 \\
\hline 2. & $\begin{array}{l}\text { dobre zdrowie, sprawność fizyczna i psy- } \\
\text { chiczna }\end{array}$ & 3,33 & 3,08 & 3,45 & 3,13 & 0,96 & 0,43 \\
\hline 3. & poczucie humoru, dowcip & 2,62 & 2,74 & 2,80 & 2,79 & 0,34 & 0,85 \\
\hline 4. & inteligencja, bystrość umysłu & 3,43 & 3,00 & 2,96 & 2,86 & 0,39 & 0,82 \\
\hline 5. & wiedza, mądrość & 3,00 & 2,87 & 2,84 & 2,85 & 0,09 & 0,98 \\
\hline 6. & radość, zadowolenie & 3,00 & 2,71 & 2,43 & 3,05 & 2,42 & 0,04 \\
\hline 7. & odwaga, stanowczość & 2,64 & 2,47 & 2,30 & 2,27 & 0,53 & 0,71 \\
\hline 8. & dobroć, delikatność & 3,50 & 2,52 & 3,29 & 3,10 & 1,60 & 0,18 \\
\hline 9. & ładny wygląd zewnętrzny, prezencja & 2,29 & 2,86 & 2,23 & 2,54 & 0,94 & 0,44 \\
\hline 10. & bogactwo, majątek & 2,20 & 3,20 & 2,53 & 2,93 & 0,72 & 0,58 \\
\hline
\end{tabular}

Źródło: opracowanie własne.

\section{Wykształcenie matki}

Kolejne analizy miały na celu wychwycenie różnic w preferowanych symbolach szczęścia i wartościach osobistych z uwzględnieniem zmiennej „poziom wykształcenia matek badanych uczniów".

Tabela 9. Symbole szczęścia preferowane przez młodzież gimnazjalną $\mathrm{z}$ uwzględnieniem poziomu wykształcenia matek

\begin{tabular}{|c|l|c|c|c|c|c|c|}
\hline \multirow{2}{*}{ Lp. } & \multicolumn{1}{|c|}{ Symbol szczęścia } & Podstawowe & Zawodowe & Średnie & Wyższe & \multirow{2}{*}{ F } \\
\cline { 3 - 6 } & $\begin{array}{c}\text { Średnia } \\
\text { waga }\end{array}$ & $\begin{array}{c}\text { Średnia } \\
\text { waga }\end{array}$ & $\begin{array}{c}\text { Średnia } \\
\text { waga }\end{array}$ & $\begin{array}{c}\text { Średnia } \\
\text { waga }\end{array}$ & F & p \\
\hline 1. & duży krąg przyjaciół & 2,80 & 3,18 & 3,06 & 3,30 & 2,39 & 0,05 \\
\hline 2. & udane życie rodzinne & 3,79 & 3,57 & 3,64 & 3,32 & 1,38 & 0,24 \\
\hline 3. & wykonywanie ulubionej pracy, zawodu & 3,46 & 3,11 & 2,66 & 2,92 & 1,28 & 0,28 \\
\hline 4. & sukcesy w nauce, pracy & 2,78 & 2,51 & 2,78 & 2,52 & 0,48 & 0,75 \\
\hline 5. & dobre zdrowie & 2,68 & 2,18 & 2,59 & 2,47 & 0,76 & 0,55 \\
\hline 6. & bycie potrzebnym innym ludziom & 2,67 & 3,27 & 3,12 & 3,27 & 1,43 & 0,22 \\
\hline 7. & dobre warunki materialne & 2,27 & 3,03 & 2,82 & 2,62 & 0,91 & 0,46 \\
\hline 8. & życie pełne przygód & 1,27 & 1,27 & 1,01 & 1,26 & 0,61 & 0,66 \\
\hline 9. & sława, popularnośćn & 2,17 & 2,44 & 2,32 & 2,50 & 0,14 & 0,96 \\
\hline
\end{tabular}

Źródło: opracowanie własne.

W przypadku symboli szczęścia wskazywanych przez młodzież istotne statystycznie różnice zaobserwowano w wyborach symbolu „posiadanie dużego kręgu 
przyjaciół” ( $\mathrm{p}=0,05)$. Jest on doceniany najbardziej wśród uczniów, których matki zdobyły wykształcenie wyższe (średnia waga - 3,3), natomiast najniższą średnią zanotowano wśród uczniów, których matki mają wykształcenie podstawowe $(2,8)$.

Przeprowadzone analizy nie pozwalają na wysnucie wniosku, że średnie wagi obliczone dla wartości osobistych deklarowanych przez badanych uczniów z uwzględnieniem poziomu wykształcenia ich matek są zróżnicowane w sposób istotny statystycznie. Należy jednak podkreślić, że poczucie humoru, dowcip uzyskały dużą średnią wagę wśród uczniów, których matki posiadają wykształcenie wyższe $(2,99 ; \mathrm{p}=0,09)$, natomiast dobre zdrowie utożsamiane ze sprawnością fizyczną i psychiczną stanowiło większą wartość dla uczniów, których matki posiadają wykształcenie podstawowe $(3,5 ; \mathrm{p}=0,10)$ niż dla pozostałych badanych.

Tabela 10. Wartości osobiste preferowane przez młodzież gimnazjalną z uwzględnieniem poziomu wykształcenia ojców

\begin{tabular}{|c|l|c|c|c|c|c|c|}
\hline \multirow{2}{*}{ Lp. } & \multicolumn{1}{|c|}{ Wartości osobiste } & Podstawowe & Zawodowe & Średnie & Wyższe & \multirow{2}{*}{ F } \\
\cline { 3 - 6 } & $\begin{array}{c}\text { Średnia } \\
\text { waga }\end{array}$ & $\begin{array}{c}\text { Średnia } \\
\text { waga }\end{array}$ & $\begin{array}{c}\text { Średnia } \\
\text { waga }\end{array}$ & $\begin{array}{c}\text { Średnia } \\
\text { waga }\end{array}$ & $\mathrm{F}$ \\
\hline 1. & miłość, przyjaźń & 4,19 & 3,65 & 3,86 & 3,63 & 0,73 & 0,57 \\
\hline 2. & $\begin{array}{l}\text { dobre zdrowie, sprawność fizyczna i psy- } \\
\text { chiczna }\end{array}$ & 3,50 & 2,80 & 3,45 & 3,24 & 1,95 & 0,10 \\
\hline 3. & poczucie humoru, dowcip & 2,07 & 2,75 & 2,72 & 2,99 & 2,03 & 0,09 \\
\hline 4. & inteligencja, bystrość umysłu & 2,92 & 3,09 & 2,90 & 3,00 & 0,19 & 0,94 \\
\hline 5. & wiedza, mądrość & 3,20 & 3,14 & 2,77 & 2,73 & 0,89 & 0,47 \\
\hline 6. & radość, zadowolenie & 2,46 & 2,76 & 2,72 & 2,72 & 0,20 & 0,94 \\
\hline 7. & odwaga, stanowczość & 2,56 & 2,39 & 2,14 & 2,63 & 1,12 & 0,35 \\
\hline 8. & dobroć, delikatnośćn & 2,67 & 2,91 & 3,06 & 3,08 & 0,33 & 0,85 \\
\hline 9. & ładny wygląd zewnętrzny, prezencja & 1,67 & 2,72 & 2,76 & 2,41 & 1,09 & 0,36 \\
\hline 10. & bogactwo, majątek & 3,00 & 3,29 & 2,70 & 2,63 & 0,49 & 0,75 \\
\hline
\end{tabular}

Źródło: opracowanie własne.

Wykształcenie matki jest czynnikiem różnicującym badanych uczniów w zakresie jednego tylko symbolu szczęścia, jakim jest duży krąg przyjaciół. Pozostałe symbole i wartości zdają się nie mieć związku z poziomem wykształcenia matek.

\section{OCENA SYTUACJI MATERIALNEJ RODZINY}

Dokonując analiz różnic między średnimi poszczególnych symboli szczęścia wśród uczniów oceniających swoją sytuację materialną jako bardzo dobrą, dobrą, przeciętną lub raczej złą, należy podkreślić istotne statystycznie różnice dla symbolu „dobre zdrowie”. Najwyżej był on oceniany przez uczniów, którzy określali sytuację 
materialną swojej rodziny jako raczej złą (średnia waga $-3,15 ; \mathrm{p}=0,00$ ). Zaobserwowano również, że uczniowie deklarujący bardzo dobrą sytuację materialną swojej rodziny uważali sławę i popularności za symbol szczęścia częściej niż uczniowie oceniający sytuację materialną swojej rodziny jako dobrą $(2,62)$, przeciętną $(1,57)$ lub złą $(1,00)$.

Tabela 11. Symbole szczęścia preferowane przez młodzież gimnazjalną z uwzględnieniem subiektywnej oceny własnej sytuacji materialnej

\begin{tabular}{|c|c|c|c|c|c|c|c|}
\hline \multirow{2}{*}{ Lp. } & \multirow{2}{*}{ Symbol szczęścia } & $\begin{array}{c}\text { Bardzo } \\
\text { dobra }\end{array}$ & Dobra & Przeciętna & $\begin{array}{c}\text { Raczej } \\
\text { zła }\end{array}$ & \multirow{2}{*}{$\mathrm{F}$} & \multirow[b]{2}{*}{$\mathrm{p}$} \\
\hline & & $\begin{array}{c}\text { Średnia } \\
\text { waga }\end{array}$ & $\begin{array}{c}\text { Średnia } \\
\text { waga }\end{array}$ & $\begin{array}{c}\text { Średnia } \\
\text { waga }\end{array}$ & $\begin{array}{c}\text { Średnia } \\
\text { waga }\end{array}$ & & \\
\hline 1. & duży krąg przyjaciół & 3,21 & 3,36 & 2,97 & 3,56 & 1,58 & 0,19 \\
\hline 2. & udane życie rodzinne & 3,35 & 3,54 & 3,71 & 3,69 & 0,75 & 0,52 \\
\hline 3. & wykonywanie ulubionej pracy, zawodu & 2,89 & 2,84 & 3,00 & 2,86 & 0,12 & 0,95 \\
\hline 4. & sukcesy w nauce, pracy & 2,73 & 2,54 & 2,62 & 2,43 & 0,25 & 0,86 \\
\hline 5. & dobre zdrowie & 2,75 & 2,11 & 2,73 & 3,15 & 4,98 & 0,00 \\
\hline 6. & bycie potrzebnym dla innych ludzi & 3,17 & 3,13 & 3,14 & 2,00 & 0,69 & 0,55 \\
\hline 7. & dobre warunki materialne & 2,64 & 2,83 & 2,62 & 3,00 & 0,36 & 0,78 \\
\hline 8. & życie pełne przygód & 0,95 & 1,19 & 1,35 & 0,69 & 1,42 & 0,24 \\
\hline 9. & sława, popularność & 2,87 & 2,62 & 1,57 & 1,00 & 2,57 & 0,06 \\
\hline
\end{tabular}

Źródło: opracowanie własne.

Tabela 12. Wartości osobiste preferowane przez młodzież gimnazjalną z uwzględnieniem subiektywnej oceny własnej sytuacji materialnej

\begin{tabular}{|c|c|c|c|c|c|c|c|}
\hline \multirow{2}{*}{ Lp. } & \multirow{2}{*}{ Wartości osobiste } & $\begin{array}{c}\text { Bardzo } \\
\text { dobra }\end{array}$ & Dobra & Przeciętna & $\begin{array}{c}\text { Raczej } \\
\text { zła }\end{array}$ & \multirow{2}{*}{$\mathrm{F}$} & \multirow{2}{*}{$\mathrm{p}$} \\
\hline & & $\begin{array}{c}\text { Średnia } \\
\text { waga }\end{array}$ & $\begin{array}{c}\text { Średnia } \\
\text { waga }\end{array}$ & $\begin{array}{c}\text { Średnia } \\
\text { waga }\end{array}$ & $\begin{array}{c}\text { Średnia } \\
\text { waga }\end{array}$ & & \\
\hline 1. & miłość, przyjaźń & 3,79 & 3,69 & 3,91 & 3,17 & 0,88 & 0,45 \\
\hline 2. & dobre zdrowie, sprawność fizyczna i psychiczna & 3,35 & 3,24 & 3,11 & 3,57 & 0,51 & 0,67 \\
\hline 3. & poczucie humoru, dowcip & 2,67 & 2,90 & 2,45 & 2,40 & 1,46 & 0,23 \\
\hline 4. & inteligencja, bystrość umysłu & 2,83 & 3,15 & 2,71 & 3,63 & 2,84 & 0,04 \\
\hline 5. & wiedza, mądrość & 2,69 & 2,91 & 2,85 & 2,67 & 0,31 & 0,81 \\
\hline 6. & radość, zadowolenie & 2,86 & 2,68 & 2,71 & 2,63 & 0,28 & 0,84 \\
\hline 7. & odwaga, stanowczość & 2,49 & 2,40 & 2,30 & 2,80 & 0,29 & 0,83 \\
\hline 8. & dobroć, delikatność & 2,96 & 2,98 & 3,27 & 3,00 & 0,36 & 0,78 \\
\hline 9. & ładny wygląd zewnętrzny, prezencja & 2,26 & 2,43 & 2,93 & 2,50 & 1,12 & 0,34 \\
\hline 10. & bogactwo, majątek & 3,05 & 2,50 & 3,13 & 3,00 & 0,85 & 0,47 \\
\hline
\end{tabular}

Źródło: opracowanie własne. 
Przeprowadzone analizy pozwalają również na stwierdzenie, że inteligencja i bystrość umysłu są wyżej oceniane przez uczniów, którzy określają sytuację materialną swojej rodziny jako raczej złą (średnia waga $-3,63 ; \mathrm{p}=0,04$ ).

Dokonana przez uczniów subiektywna ocena sytuacji materialnej ich rodzin jest zatem czynnikiem różnicującym postrzeganie dobrego zdrowia jako symbolu szczęścia oraz inteligencji i bystrości umysłu jako preferowanych wartości osobistych.

\section{DYSKUSJA O WYNIKACH I OGRANICZENIA BADAŃ}

Wyniki analiz nie odbiegają znacznie od uzyskanych przez innych badaczy. W 2011 roku Anna Witek, Teresa Lewandowska-Kidoń i Agnieszka Pawluk-Skrzypek wśród 50 uczniów radomskich gimnazjów przeprowadziły badania na temat percepcji otyłości i przekonań zdrowotnych. Jednym z etapów analizy otrzymanych wyników była próba wyodrębnienia wartości niezbędnych do odczuwania szczęścia przez uczniów. Średnie rangi najważniejszych dla badanych symboli szczęścia w dużej mierze pokrywają się z wynikami otrzymanymi przez autorkę niniejszego opracowania. Uczniowie utożsamiają szczęście z dużym kręgiem przyjaciół $(2,97)$ i udanym życiem rodzinnym $(3,30)$. Najniższą średnią wagę uzyskały sława, popularność $(0,18)$ oraz życie pełne przygód, podróży $(1,20)$. Analiza preferowanych wartości pozwala na wysnucie stwierdzenia, że najważniejsze dla młodzieży są wartości uniwersalne, jak: miłość, przyjaźń $(3,59)$, dobre zdrowie, sprawność psychiczna i fizyczna (2,02). Natomiast wartości typowo hedonistyczne jak bogactwo, majątek $(0,81)$ czy ładny wygląd zewnętrzny, prezencja $(0,69)$ zdają się nie mieć dla badanych większego znaczenia (Witek $\mathrm{i}$ in. 2011).

Istotne ze względu na zadania edukacji zdrowotnej i promocji zdrowia jest określenie, jakie miejsce wśród symboli szczęścia i wyznawanych wartości osobistych zajmuje dobre zdrowie. W badaniach innych autorów (Chmiel-Połeć i in. 2007) zdrowie zajęło najwyższą pozycję, co jednak nie pokrywa się z analizami przeprowadzonymi przez autorkę niniejszego opracowania. Również badania Igi Grad i Katarzyny Kiliś-Pstrusińskiej (2015) przeprowadzone na grupie 242 uczniów liceum ogólnokształcącego wykazało, że tylko 30\% badanych dobre zdrowie uznaje za najważniejszą wartość, przyznając mu piątą, najwyższą rangę. Wzmocnienie zdrowia jako wartości w życiu młodzieży autorki badań przedstawiają jako element ważny ze względu na konieczność wpajania zachowań prozdrowotnych, które mają stanowić czynnik chroniący przed schorzeniami cywilizacyjnymi.

Analizy innych autorów (por. Moir, Jessel 1993; Zalewska 1987), wskazują, że kobiety od najmłodszych lat bardziej niż mężczyźni wrażliwe są na bodźce 
społeczne, ujawniają większą empatię oraz większe zainteresowanie relacjami interpersonalnymi, ale badania przeprowadzone przez autorkę niniejszego opracowania nie potwierdzają tego faktu. Płeć nie stanowiła czynnika różnicującego badanych w zakresie żadnego z symboli szczęścia i wartości osobistych.

Należałoby pow tórzyć badania z uwzględnieniem większej liczby respondentów (ważne jest zapewnienie reprezentatywności). Interesujące mogłoby być porównanie uczniów III i IV etapu edukacyjnego.

\section{PODSUMOWANIE}

Analizy socjodemograficznych korelatów wartości i symboli szczęścia wyznawanych przez uczniów nie potwierdziły, że takie zmienne, jak płeć, miejsce zamieszkania, wykształcenie rodziców czy subiektywna ocena sytuacji materialnej stanowią istotny czynnik różnicujący wyniki. Jedynie w przypadku niektórych wskaźników można było zaobserwować istotne statystycznie różnice między średnimi.

Płeć nie stanowi czynnika różnicującego badanych w omawianym zakresie. Ważniejsze są zapewne rodzinne, szkolne i osobiste uwarunkowania wynikające z całokształtu procesu wychowania i edukacji. W przypadku miejsca zamieszkania jedynie miłość i przyjaźn różnicowały badanych - były to wartości wyżej cenione wśród mieszkańców dużych miast i wsi niż wśród badanych pochodzących z małych miast. Wykształcenie rodziców różnicowało natomiast badanych w przypadku zaledwie dwóch wskaźników. Uczniowie, których ojcowie posiadali wykształcenie wyższe, wyżej cenili radość i zadowolenie. Być może związane jest to $\mathrm{z}$ większym optymizmem towarzyszącym często większej świadomości przeżywanego życia i jego podwyższonym standardem. Natomiast uczniowie, których matki posiadały wyższe wykształcenie, wyżej cenili duży krąg przyjaciół niż pozostali. Można mniemać, że matki tychże uczniów są bardziej świadome roli, jaką pełnią kontakty interpersonalne i społeczne wsparcie. Sytuacja materialna badanych uczniów różnicowała ich w zakresie postrzegania dobrego zdrowia jako symbolu szczęścia. To uczniowie, którzy sytuację materialną swojej rodziny określali jako raczej złą, przypisywali dobremu zdrowiu wyższą wartość niż inni. Warunki materialne w dużej mierze decydują o stylu życia i podejmowaniu działań związanych ze zdrowiem. Brak środków do zapewnienia podstawowych potrzeb może wiązać się z zachowaniami o negatywnych i skutkach dla zdrowia (spożywaniem produktów niskiej jakości, niedoborem składników odżywczych, a co z tym związane - mniejszą odpornością). Osoby o niższym statusie materialnym częściej doświadczają problemów ze zdrowiem wynikających z nieodpowiedniego stylu życia. Natomiast uczniowie określający status materialny swojej rodziny 
jako bardzo dobry przyznawały wyższą średnią wagę symbolowi szczęścia, jakim jest sława i popularność. Możliwe, że dzięki wyższemu statusowi materialnemu, który zapewnia zaspokojenie podstawowych potrzeb, upatrują szczęścia w innych celach, często związanych z rozwijaniem swoich pasji i marzeń.

Podsumowując, należy zaznaczyć, że wartości deklarowane przez młodzież kształcącą się w gimnazjum są zazwyczaj uniwersalne i odnoszące się do rodziny, przyjaciół, dobrego zdrowia. Wartości hedonistyczne były przez młodzież dość rzadko wybierane, a jeśli już - przypisywano im niskie rangi. Należy jednak podkreślić, że przeprowadzone badania miały charakter wyłącznie deklaratywny, co stanowi jeden z problemów metodologicznych, który dotyczy badanego zjawiska.

Główny wniosek wypływający z otrzymanych wyników wskazuje, że konieczne jest podkreślanie ważności sfery aksjologicznej w dzisiejszym, tak szybko zmieniajacym się świecie. O konieczności tej trafnie pisze Waldemar Furmanek (2010, s. 24):

Ów „nowy nieporządek świata” dotyczy przede wszystkim świata wartości. Konieczna jest budowa nowej, odmiennej jakościowo przestrzeni wartości. Pojawiają się z całą wyrazistością - obok dylematów rozwojowych - dylematy etyczne, takie jak: rozwijanie się konfliktów na tle politycznym, religijnym, plemiennym; proponowanie przyjęcia tzw. „opcji zerowej”; utylitaryzm moralny: konsumpcjonizm, rozwój postaw hedonistycznych, relatywizm moralny; podważanie wartości autorytetów moralnych; akceptacja swobód, odrzucanie obowiązków i odpowiedzialności; kult pieniądza i kategorii MIEĆ zamiast BYĆ; pogarda dla etosu pracy człowieka.

Szczególną rolę na etapie adolescencji należy przypisać rodzicom, ale także nauczycielom, którzy - obcując na co dzień z młodymi ludźmi - uczestniczą pośrednio w budowaniu ich systemu wartości, do którego będą odnosić się przez całe życie.

\section{LITERATURA}

Chmiel-Połeć Z., Boratyn-Dubiel L., Binkowska-Bury M., 2007, Palenie papierosów wśród gimnazjalistów powiatu rzeszowskiego. „Przegląd Lekarski” 2007, z. 64, t. $10,762-766$.

Domalewski J., 2013, System wartości młodzieży gimnazjalnej. Raport z badań przeprowadzonych wśród uczniów klas III gimnazjów województwa kujawsko-pomorskiego. Bydgoszcz-Toruń, Kuratorium Oświaty w Bydgoszczy. 
Dubis M., 2014, Wartości i style życia młodzieży. W: P. Długosz, M. Niezgoda, S. Solecki (red.), Młodzież w społeczeństwie ryzyka. Kraków, Wydawnictwo UJ, 35-47.

Dziewiecki M., 2003, Osoba i wychowanie. Kraków, Wydawnictwo Rubikon.

Furmanek W., 2010, Wyzwania edukacji wobec kolejnych fal przemian cywilizacyjnych. „Edukacja-Technika-Informatyka”, t. 1(2), 13-27.

Furmanek W., 2011, Introcepcja wartości. W: W. Furmanek (red.), Teoria i praktyka wartości w pedagogice. Rzeszów, Wydawnictwo UR, 76-95.

Grad I., Kiliś-Pstrusińska K., 2015, Postrzeganie zdrowia jako wartości osobistej przez młodzież szkół licealnych. „Family Medicine \& Primary Care Review”, nr 1, 19-23.

Juczyński Z., 2009, Narzędzia pomiaru w promocji i psychologii zdrowia. Warszawa, Pracownia Testów Psychologicznych.

Marzec-Tarasińska A., 2014, Wartości cenione, ale czy urzeczywistniane przez wspótczesna młodzież? W: A. Odrowąż-Coates, M. Kwiatkowski (red.), Przyszłość edukacji i społeczeństwa oczami badaczy społecznych. Warszawa, Wydawnictwo APS, 144-154.

Mariański J., 2009, Dylematy moralne młodzieży polskiej. W: D. Walczak-Duraj (red.), Wartości i postawy młodzieży polskiej. Łódź, Wydawnictwo UŁ, 11-28.

Moir A., Jessel D., 1993, Płeć mózgu. Warszawa, Państwowy Instytut Wydawniczy.

Ponczek D., Olszowy I., 2012, Styl życia młodzieży i jego wplyw na zdrowie. „Problemy Higieny i Epidemiologii", t. 93(2), 260-268.

Reykowski J., 1977, Osobowość jako centralny system regulacji i integracji czynności człowieka. W: T. Tomaszewski (red.), Psychologia. Warszawa, Wydawnictwo Naukowe PWN, 762-825.

Witek A., Lewandowska-Kidoń T., Pawluk-Skrzypek A., 2012, Percepcja otyłego rówieśnika a przekonania zdrowotne młodzieży gimnazjalnej. „Medycyna Ogólna i Nauki o Zdrowiu", t. 18, nr 4, 276-280.

Zalewska A., 1997, Cele życiowe licealistów i studentów w zależności od reaktywności i ptci. „Psychologia Wychowawcza”, t. 40, nr 1, 12-24.

Zawada A., 2003, Aspiracje życiowe młodzieży w środowisku kulturowo zróżnicowanym. Kraków-Katowice, Oficyna Wydawnicza Impuls.

\author{
PERSONAL VALUES PREFERRED BY SECONDARY SCHOOL \\ STUDENTS -A SELECTED SOCIODEMOGRAPHIC INDICATORS
}

Abstract: One of the basic tasks of development at the stage of adolescence is the formation of an individual hierarchy of values, which in later stages of life is a fully regulatory function in daily life activities and choices. Numerous studies indicate that young people declared preferring 
universal values, and, to a small degree, those which are considered typically hedonistic. In order to diagnose with which symbols the youth equate happiness and what values in life are paramount, and whether and to what extent selected socio-demographic factors differ in this field, a student study was conducted using the method of a diagnostic survey. As a tool there was used a List of Personal Values by Siegfried Juczyński. 375 junior high school students from the Lublin Province were examined. Personal values declared by young people usually refer to family, friends, good health. Hedonistic values chosen by respondents were rarely ascribed a low rank. Socio-demographic factors such as a place of residence, parents' education and a subjective assessment of the situation of the family differentiated pupils only in terms of individual symbols of happiness and personal values. Gender was not a factor differentiating the respondents in this area. Axiological sphere is subject to social, cultural, educational constant change. Important in this regard seem to be activities aimed at education towards values.

Keywords: secondary school students, the hierarchy of values, symbols of luck. 